\title{
Does forest management and researchers' presence reduce hunting and forest exploitation by local communities in Tsitongambarika, south-east Madagascar?
}

\author{
Marco Campera, Megan Phelps, Fiona Besnard, Michela Balestri \\ Timothy M. Eppley, Vincent Nijman and Giuseppe Donati
}

\begin{abstract}
Hunting of wildlife is one of the major threats to biodiversity. For effective conservation programmes in countries where hunting and shifting agriculture are the main sources of subsistence, forest management should aim to reduce hunting pressure and forest exploitation. The presence of researchers has been promoted as one of the main ways to mitigate anthropogenic pressures on wildlife populations. Our aim was to test whether local management and the establishment of a research station had a role in decreasing forest exploitation by local people living adjacent to a recently protected area in south-east Madagascar. We interviewed local people from nine villages at various distances from the recently established research station of Ampasy, in the northernmost portion of the Tsitongambarika Protected Area, to explore how people use the forest, with a particular focus on hunting. We also performed transect surveys to estimate snare and lemur encounter rates before local forest management began, at the establishment of the research station, and 1 year after. The impact of local communities on the forest seems to have decreased since the beginning of forest management, with a further decrease since the establishment of the research station. Participants from villages not involved in the local management were more reluctant to declare their illegal activities. We conclude that a combination of local management and related activities (e.g. installation of a research station) can assist in temporarily reducing forest exploitation by local communities; however, community needs and conservation plans should be integrated to maintain long-term benefits.
\end{abstract}

Keywords Forest management, hunting, lemurs, Madagascar, pirogue, research station, snares, Tsitongambarika

Marco Campera (Corresponding author), Megan Phelps, Fiona Besnard, Michela Balestri, Vincent Nijman and Giuseppe Donati Department of Social Sciences, Oxford Brookes University, Gibbs Building, Gipsy Lane, Oxford, OX3 0BP, UK. E-mail marco.campera-2013@brookes.ac.uk

Tiмотнy M. Eppley Biozentrum Grindel, Department of Animal Ecology and Conservation, University of Hamburg, Hamburg, Germany, and San Diego Zoo Global, Institute for Conservation Research, San Diego, USA

Received 31 March 2017. Revision requested 24 May 2017.

Accepted 25 July 2017. First published online 20 November 2017.

\section{Introduction}

T unting of wildlife, mainly for commercial purposes, is 1 one of the major threats to biodiversity (Nijman, 2010; Jenkins et al., 2011) and has significantly reduced wildlife populations (Rao et al., 2011; Melo et al., 2015). Long-lived species with slow reproductive rates are particularly affected (Rao et al., 2011). Various methods have been used to estimate hunting pressure, each with strengths and weaknesses. Market surveys are a common way to estimate the level of hunting (Allebone-Webb et al., 2011), although this method does not account for subsistence hunting (Golden et al., 2013). An alternative method is to estimate the density of snares (Barelli et al., 2015) but this does not consider opportunistic hunting. Interviews are frequently used to estimate hunting pressure or bushmeat consumption (Rao et al., 2011; Golden et al., 2013), but obtaining reliable responses is a challenge, as participants may be reluctant to declare illegal activities (Knapp et al., 2010; Nuno \& St John, 2015). Another approach involves estimating population fluctuations by monitoring the density of animals over time, although in this case it is difficult to separate the effects of hunting from those of other ecological factors (Barelli et al., 2015; Melo et al., 2015).

For effective conservation programmes in countries where hunting and shifting agriculture are the main sources of subsistence, forest management and the creation of alternative sources of income should bring about a reduction in hunting pressure and forest exploitation, but local stakeholder and community perceptions should be taken into account (Hill, 1997). Previous studies (e.g. Newmark et al., 1993; Little, 1994) have suggested that even a minor interaction between NGOs, research organizations and local communities can have a positive impact on attitudes towards wildlife. However, several studies have reported failure of forest management programmes, mainly as a result of a lack of longterm funding (e.g. Little, 1994; Webber et al., 2007).

In addition to forest management, the presence of researchers has been recognized as a factor in reducing anthropogenic pressures on threatened species (Marsh et al., 1999; Wrangham \& Ross, 2008; Schwitzer et al., 2014). This is based on the rationale that local communities may decrease their hunting activity and exploit the forest less, as a 
consequence of receiving direct benefits from researchers' presence, such as new job opportunities (Wrangham \& Ross, 2008; Schwitzer et al., 2014). Researchers can also provide training to local assistants, as well as increase awareness of the importance of the forest, and this is likely to facilitate future research and ecotourism (Schwitzer et al., 2014). Evidence to support the hypothesis that researcher presence decreases hunting pressure comes from two studies that investigated the abundance of primates in Tai National Park, Ivory Coast (Campbell et al., 2011; N'Goran et al., 2012); these studies found a positive association between species densities and distance to the research station, as a result of lower hunting pressure close to the research station. Furthermore, long-term research in an area has been linked to an increase in wildlife population size (Fedigan \& Jack, 2012; Nakamura, 2012), although this has not been linked directly to the presence of a research station. However, the opposite has also been reported, with a population of primates having been hunted to near-extirpation despite the presence of a large, fully operational field station (Nijman, 2005). Similarly, but without presenting data to support their claims, Bezanson et al. (2013) argued that the presence of researchers, and especially the establishment of extensive trail systems, facilitates greater access and increased opportunities for poaching.

Madagascar is a biodiversity hotspot in which many endemic species are threatened (Myers et al., 2000). Ninetyfour percent of lemurs, one of the island's flagship taxonomic groups, are threatened with extinction (Schwitzer et al., 2014). Hunting of wildlife is mostly for subsistence (Razafimanahaka et al., 2012; Golden et al., 2014), as bushmeat is a cheap alternative to domesticated meat (Golden et al., 2014; Borgerson et al., 2016), and poverty, poor health and child malnutrition are strong predictors of illegal hunting (Borgerson et al., 2016). It has been suggested that bushmeat consumption is more widespread than previously thought (Golden, 2009), based on recent studies (e.g. Razafimanahaka et al., 2012; Golden et al., 2014; Borgerson et al., 2016).

The Tsitongambarika Protected Area, in south-eastern Madagascar, was established in 2008 (BirdLife International, 2011) and has been co-managed by the NGO Asity Madagascar (BirdLife Madagascar) and KOMFITA (Community Forest Management) since 2013. A research station was established in 2015 at Ampasy, in the northernmost portion of the protected area. The Tsitongambarika forest is a good model with which to test the influence of a research station on a forest area, as no long-term research had been conducted in the area prior to the establishment of the research station, and thus local communities had not had prolonged exposure to researchers. Furthermore, this area has no exposure to tourism, which can be a potentially confounding factor (Krüger, 2005; Wright et al., 2014).

Our aim was to evaluate the determinants reducing pressure on lemur populations in the northernmost portion of Tsitongambarika. We hypothesized that the presence of

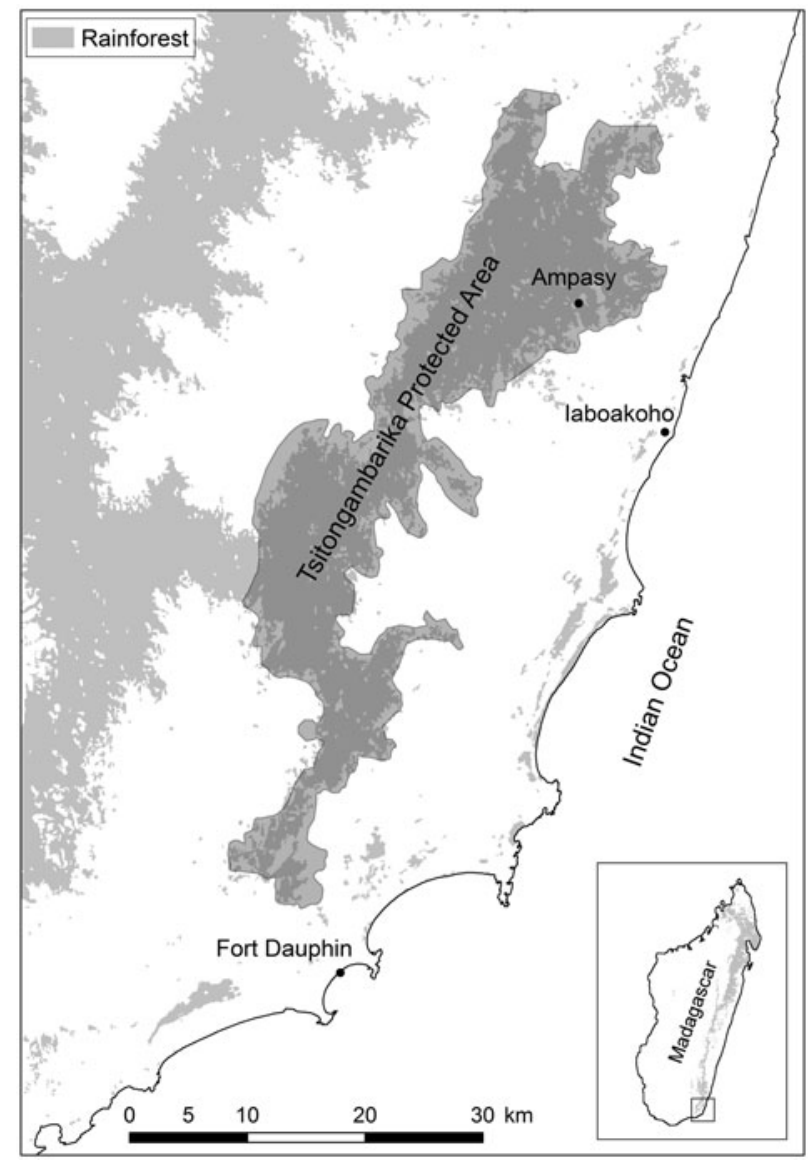

FIg. 1 Location of the study area in the Tsitongambarika Protected Area, in south-east Madagascar.

researchers and local forest management significantly benefit lemur communities and the forest. In particular, we predicted that (1) anthropogenic pressure on the forest was reduced after local management commenced; (2) people from villages close to the research station and involved in the local management of the forest decreased their forest use following the establishment of the research station more than people from villages further away, and villages not involved in the local management did not decrease their impact on the forest; (3) the occurrence of active snares was greater prior to the start of local management, and decreased substantially after the research station was established; (4) rates of encounter with cathemeral (i.e. active at any time of night or day; Donati et al., 2016) lemurs increased after the research station was established, as they are expected to be the main targets of hunting, given their comparatively large body size.

\section{Study area}

The study was conducted at the Ampasy research station, in the northernmost portion of Tsitongambarika (Fig. 1). The research station is located at the forest edge in the Ampasy Valley, c. $7.6 \mathrm{~km}$ from Iaboakoho (c. $60 \mathrm{~km}$ north of Fort 
TABLE 1 Number and percentage of households censused during semi-structured interviews in villages in the municipality of Iaboakoho, in south-east Madagascar (Fig. 1). The villages are categorized based on distance from the research station of Ampasy and continuous forest, and whether or not they are involved in local forest management.

\begin{tabular}{lll}
\hline Village category & $\begin{array}{l}\text { No. of households } \\
\text { censused (\%) }\end{array}$ & $\begin{array}{l}\text { Estimated no. of } \\
\text { households in village* }\end{array}$ \\
\hline Close-involved & $22(40)$ & 55 \\
Close-not involved & $20(36)$ & 55 \\
Far-involved & $30(14)$ & 210 \\
Total & $72(23)$ & 320 \\
\hline
\end{tabular}

*Based on observations by the researchers and published data from BirdLife International (2011)

Dauphin). Local people depend mainly on fishing and traditional practices, including shifting agriculture (BirdLife International, 2011). They also depend on the forest for timber, firewood, medicinal plants, and lianas to make lobster traps, although the importance of hunting in the area is not well-known and has potentially been underestimated in previous reports (BirdLife International, 2011). Hunting in Tsitongambarika has been reported to be a major threat to the collared brown lemur Eulemur collaris, and other endemic species are also targeted, including the southern bamboo lemur Hapalemur meridionalis, the Madagascan flying fox Pteropus rufus, the fossa Cryptoprocta ferox and the blue coua Coua caerulea (BirdLife International, 2011).

\section{Methods}

\section{Interviews}

We collected data via semi-structured household interviews (Golden, 2009) from nine villages in the municipality of Iaboakoho, selecting a maximum of 10 people from each village. In total, 72 people were interviewed in June 2016 (Table 1). We included all villages within two hours' walk of the research station.

A translator with previous experience and who speaks the local dialect was hired to assist with the interviews. Additionally, a local guide helped in recruiting male heads of households, asking for their participation in interviews. Convenience sampling was used to select interview participants, selecting those available in the village at a given time (Henn et al., 2009). The interview included eight questions (Table 2), starting with general questions on forest use, followed by more specific questions about hunting. Indirect questioning techniques (Nuno \& St John, 2015) were employed to minimize dishonest answers, although we cannot exclude the presence of false negatives.

Following the questions, a series of 16 photographs were presented (Table 3), each of a different endemic animal species we had observed in Tsitongambarika since research began at Ampasy. We asked if the respondent had seen each animal, and whether or not they had eaten it. Pictures were tested with four local guides to ensure easy recognition. We asked interviewees to independently (i.e. one-by-one) provide the vernacular names of the species shown, assuring the overall consensus for each picture. To maximize the reliability of data, images were not limited to lemur species, as we did not want to reveal our main research focus (participants may have avoided answering honestly if they knew our focal species; Nuno \& St John, 2015).

\section{Snare and lemur counts}

We established 11 transects of $1 \mathrm{~km}$ length using pre-existing trails. We evaluated the number of snares by walking all transects after the research station was established (May 2015) and at the end of the study (July 2016). We counted all traps visible up to $20 \mathrm{~m}$ from the transect. We also considered data collected in July 2012, before local management began in the Ampasy Valley (Nguyen et al., 2013). The same transects were walked in 2012 and 2015, although more areas were surveyed in 2012. We plotted the global positioning system coordinates of the snares found, to compare the data collected in 2012 with our data, considering only traps along our established transects. Eleven of the 16 traps found in 2012 (Nguyen et al., 2013) were located within the area monitored in 2015. Nine of our 11 transects occurred in the forest, and we walked each transect once per month during May-July 2015 and May-July 2016 to estimate encounter rates of collared brown lemurs and southern bamboo lemurs. Transects were walked at a mean speed of c. $1.0-1.5 \mathrm{~km}$ per hour, starting in the early morning (06.30-07.30) or late afternoon (15.00-16.00).

\section{Ethics statement}

Research was approved by the Oxford Brookes University Ethics Committee. We obtained permission from the Ministry of Environment and Forest (54/16/MEEMF/SG/ DGF/DAPT/SCBT.Re). In conformity with local customs, we asked for consent from the mayor of the Iaboakoho municipality before commencing interviews. Before each interview we explained all research details to participants, avoiding revealing our main target (i.e. lemur hunting) to favour honest responses (Nuno \& St John, 2015), stating that participation was voluntary, with the opportunity to withdraw at any time. Village names are not provided here, to ensure anonymity of participants.

\section{Data analysis}

For interviews, we grouped villages into three categories depending on the distance from the research station/ 
TABLE 2 Questionnaire used to estimate the level of forest exploitation by inhabitants of villages at various distances from the Ampasy research station (Fig. 1), in the northernmost part of the Tsitongambarika Protected Area.

\begin{tabular}{ll}
\hline Question & Potential answers \\
\hline 1. How often do you go into the forest now? & Daily, weekly, monthly, rarely, never \\
2. Did you visit the forest more often before local management by Asity began? & Yes, no \\
3. Why do you use the forest? (Tick all that apply) & Firewood, timber, pirogues, hunting, other \\
4. Which animals did you hunt? & Open question \\
5. What did you do the last time you went into the forest? & Open question \\
6. When was the last time you ate a lemur ${ }^{1}$, and how did you get it? & Before 2013, after $2013^{2}$; second part was open question \\
7. Do you think people from your village hunt now? & They hunt, they do not hunt, do not know \\
8. Do you think people from the neighbouring villages hunt now? & They hunt, they do not hunt, do not know \\
\hline
\end{tabular}

${ }^{1}$ Gidro in the local dialect.

${ }^{2}$ The translator asked if the last time they ate a lemur was before or after local management began in 2013.

TABLE 3 Common, scientific and vernacular names, order and IUCN status of species shown in photographs during interviews in villages in the municipality of Iaboakoho (Fig. 1), with the percentages of interview participants who reported having eaten and seen the species.

\begin{tabular}{|c|c|c|c|c|c|}
\hline Species & Vernacular name & Order & IUCN status* $^{*}$ & $\begin{array}{l}\text { Ate the } \\
\text { species (\%) }\end{array}$ & $\begin{array}{l}\text { Saw the } \\
\text { species (\%) }\end{array}$ \\
\hline Striped civet Fossa fossana & Aparo & Carnivora & VU & 63.8 & 87.0 \\
\hline Fossa Cryptoprocta ferox & Fossa & Carnivora & VU & 26.1 & 56.5 \\
\hline Broad-striped mongoose Galidictis fasciata & Voatsira fotsy & Carnivora & VU & 18.8 & 66.7 \\
\hline Ring-tailed mongoose Galidia elegans & Voatsira mena & Carnivora & VU & 49.3 & 98.6 \\
\hline Madagascan flying fox Pteropus rufus & Fanihy & Chiroptera & VU & 68.1 & 100.0 \\
\hline Peters's sheath-tailed bat Paremballonura atrata & Kananavy & Chiroptera & LC & 72.5 & 100.0 \\
\hline Aye-aye Daubentonia madagascariensis & Aye-aye & Primates & $\mathrm{EN}$ & 0.0 & 29.1 \\
\hline Southern woolly lemur Avahi meridionalis & Fotsy fe & Primates & EN & 43.5 & 89.9 \\
\hline Southern bamboo lemur Hapalemur meridionalis & Halo & Primates & VU & 75.4 & 98.6 \\
\hline Greater dwarf lemur Cheirogaleus major & Matavirambo & Primates & DD & 31.9 & 84.1 \\
\hline Fleurete's sportive lemur Lepilemur fleuretae & Pondiky & Primates & CR & 32.9 & 80.0 \\
\hline Anosy mouse lemur Microcebus tanosi & Tsitsidy & Primates & NA & 39.1 & 95.7 \\
\hline Collared brown lemur Eulemur collaris & Varika & Primates & EN & 79.7 & 95.7 \\
\hline Blue coua Coua caerulea & Tesso & Cuculiformes & LC & 55.1 & 100.0 \\
\hline Brown mesite Mesitornis unicolor & Deho & Mesitornithiformes & VU & 92.8 & 100.0 \\
\hline Madagascar red owl Tyto soumagnei & Vorondolo & Strigiformes & VU & 1.4 & 97.1 \\
\hline
\end{tabular}

${ }^{*}$ DD, Data Deficient; LC, Least Concern; VU, Vulnerable; EN, Endangered; CR, Critically Endangered; NA, Not Assessed

continuous forest and the potential influence of local management: close-involved, close-not involved, far-involved. Villages in the close-involved category were those closest to the research station $(4.3-5.0 \mathrm{~km})$ and continuous forest $(2.1-3.3 \mathrm{~km})$ that were involved in the local management of the forest, especially after the research station was established, and for which the Ampasy Valley was the preferred point of access to the forest. Villages categorized as close-not involved were those close to the research station $(4.3-5.0 \mathrm{~km})$ and continuous forest $(2.1-3.3 \mathrm{~km})$ that were not involved, or were only marginally involved, in the local management and for which another valley was the preferred point of access to the forest. Villages categorized as far-involved were those furthest from the research station $(6.2-7.6 \mathrm{~km})$ and continuous forest $(4.2-4.7 \mathrm{~km})$ that were involved in the local management from the beginning, and for which the Ampasy Valley was the preferred point of access to the forest. To calculate the distance from the research station/continuous forest, we plotted global positioning system coordinates for each village in ArcGIS v. 10.4 (ESRI, Redlands, USA) and calculated the straight-line distance to the research station/continuous forest. We considered a village to be involved in the local management of the forest when more than half of the inhabitants were employed by Asity-KOMFITA, received funding from Asity-KOMFITA to support sustainable agriculture, and/or participated in conservation education programmes promoted by AsityKOMFITA (Razafitsalama \& Ravoahangy, 2010). We considered the household a statistical unit, and we ran multiple generalized linear models to test the influence of distance/management on the variables derived from the interviews. Villages were considered as subjects, as people within each village may show similar habits more often than people from different villages in the same distance-management category. Variables 


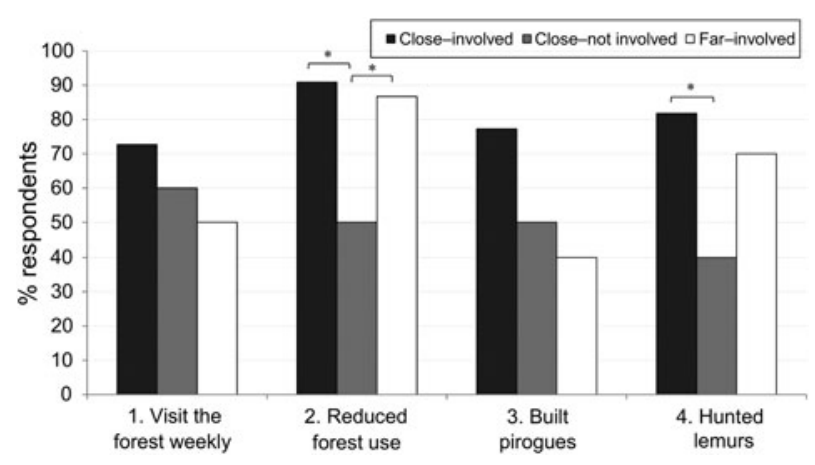

FIG. 2 The percentage of interview participants who reported visiting the forest weekly, having reduced their forest use since local management by Asity began, building pirogues in the forest, and hunting lemurs, in response to questions 1-4 (Table 2), categorized according to distance from the research station at Ampasy (Fig. 1) and continuous forest, and involvement in local forest management. ${ }^{\star} \mathrm{P}<0.05$.

were linked to logistic/probit (in the case of binary and ordinal variables) or log-linear Poisson/log-negative binomial (in the case of counts) distributions. The lower value of the Quasi-likelihood under Independence Model Criterion was used to select the link function. In the case of open questions, we categorized answers (see Results) to facilitate statistical comparison. Fisher's least significant difference post-hoc tests were performed for pairwise comparisons in the case of significant effects. We report only significant results for post-hoc tests.

For snares, we performed Wilcoxon tests between trap counts per transect in 2012 and 2015 to test whether there was a reduction as a result of local management, and between 2015 and 2016 to test whether there was a further reduction as a result of the presence of the research station. To test whether encounters with cathemeral lemurs increased from May-July 2015 to May-July 2016 we performed a Wilcoxon test, comparing the same transect per month between years. Statistical tests were performed in SPSS 22 (IBM, Armonk, USA), using a significance level of $\mathrm{P}<0.05$.

\section{Results}

Interviews

Overall, $20.8 \%$ of participants entered the forest daily, $38.9 \%$ weekly, $16.7 \%$ monthly, $18.1 \%$ rarely, and $5.6 \%$ never. No significant differences were found between villages in the number of people who used the forest at least once per week (Fig. 2; distance-management effect: Wald $\chi^{2}=1.861$, $\mathrm{P}=0.394)$.

Before local management began, $77.8 \%$ of participants used the forest more frequently than they do now, with significant differences between villages (Fig. 2; distance-management effect: Wald $\chi^{2}=13.536, \mathrm{P}=0.001$ ). Fewer people from villages in the close-not involved category

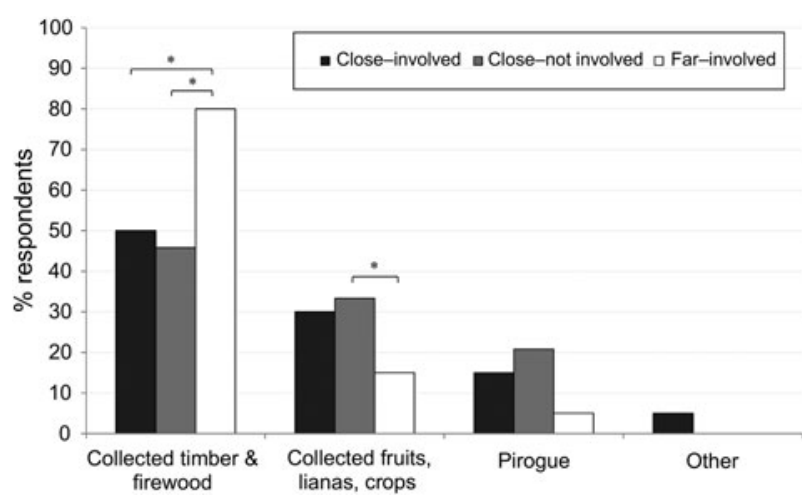

FIG. 3 The percentage of interview participants who chose each of the responses to question 5 (What did you do the last time you went into the forest Table 2), categorized according to distance from the research station at Ampasy (Fig. 1) and continuous forest, and involvement in local forest management. ${ }^{\star} \mathrm{P}<0.05$.

acknowledged they had reduced their forest use after the introduction of local management compared to villages in the close-involved $(\mathrm{P}=0.001)$ and far-involved $(\mathrm{P}=0.001)$ categories.

All participants used the forest for timber and firewood. Many participants (54.2\%) used the forest to build pirogues (dug-out canoes made mainly from the tree Calophyllum inophyllum). The percentage of people who built pirogues (Fig. 2) did not vary between villages (distance-management effect: Wald $\chi^{2}=\mathbf{2 . 0 2 2}, \mathrm{P}=0.364$ ). For hunting, we considered only participants who said they hunted lemurs. Overall, $65.3 \%$ of participants used the forest to hunt lemurs. This percentage varied between villages (distance-management effect: Wald $\chi^{2}=7.289, \mathrm{P}=0.026$; Fig. 2). People in villages categorized as close-not involved reported hunting lemurs less frequently than people living in villages categorized as close-involved $(\mathrm{P}=0.003)$.

The answers to question 5 (What did you do the last time you went into the forest?) were 'collected timber or firewood' (57.8\%), 'collected fruits, lianas or crops' (26.6\%), 'built pirogues' (14.1\%), and 'fished' (1.6\%) (Fig. 3). Distance-management was a significant factor determining the answer 'collected timber or firewood' (Wald $\chi^{2}=14.016$, $\mathrm{P}=0.001$ ). In particular, people from villages categorized as far-involved gave this answer more than those in close-involved $(\mathrm{P}=0.046)$ and close-not involved $(\mathrm{P}<0.001)$ villages. Distance-management was also a significant factor determining the answer 'built pirogues' (Wald $\chi^{2}=8.306$, $\mathrm{P}=0.016$ ). In particular, people from villages categorized as close-not involved gave this answer more often than those in far-involved villages $(P=0.008)$. There were no differences between villages for the answer 'collected fruits, lianas or crops' (distance-management effect: Wald $\left.\chi^{2}=0.594, P=0.743\right)$.

When asked about the last time they ate lemurs, $18.6 \%$ of participants said it was after local management had begun, 


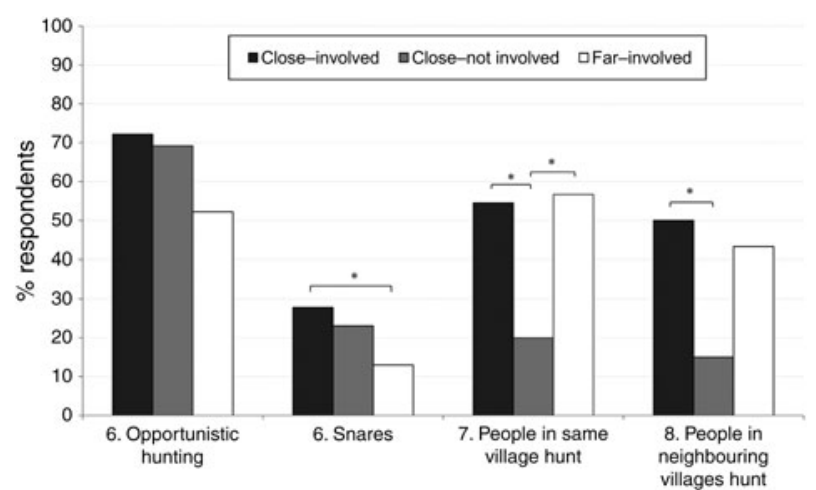

FIG. 4 The percentage of interview participants who reported catching lemurs by opportunistic hunting and snares, that people in their village hunted, and that people in neighbouring villages hunted, in response to questions 6-8 (Table 2), categorized according to distance from the research station at Ampasy (Fig. 1) and continuous forest, and involvement in local forest management. ${ }^{\star} \mathrm{P}<0.05$

and $8.6 \%$ stated they never ate lemurs. In response to a followup question (How did you procure it?), 63.0\% answered 'opportunistic hunting' (mainly via slingshot), $20.4 \%$ answered 'snares', and $16.7 \%$ answered it was a 'gift' from relatives/ friends. Opportunistic hunting was not dependent on distance-management (Wald $\chi^{2}=2.151, \mathrm{P}=0.341$ ) but the use of snares was (Wald $\chi^{2}=23.390, \mathrm{P}<0.001$ ), with more participants who reported using snares in close-involved than in far-involved villages $(\mathrm{P}<$ o.oo1; Fig. 4).

In response to the question 'Do you think that people from your village hunt now?' $45.8 \%$ of participants said that people in their village still hunted, $25.0 \%$ said that people from their village hunted previously, and $29.2 \%$ did not know. The answer was different between villages (distancemanagement effect: Wald $\chi^{2}=8.712, \mathrm{P}=0.013$ ), with participants in villages categorized as close-not involved responding less frequently that people in their village still hunted than participants in far-involved $(\mathrm{P}=0.016)$ and close-involved $(\mathrm{P}=0.048)$ villages. Overall, $37.5 \%$ of people interviewed answered that people in neighbouring villages still hunted, $19.5 \%$ said that people from their village hunted previously, and $43.1 \%$ did not know. The answer to the question 'Do you think that people from the neighbouring villages hunt now?' differed significantly between villages (distance-management effect: Wald $\chi^{2}=6.438, P=0.040$ ). Fewer people living in close-not involved villages declared that people from neighbouring villages still hunted, compared to people living in close-involved villages ( $\mathrm{P}=$ 0.049; Fig. 4).

The number of species eaten by participants (Fig. 5) differed significantly between villages (distance-management effect: Wald $\chi^{2}=15.393, \mathrm{P}<0.001$ ). People living in villages categorized as close-not involved declared they ate fewer species than those living in villages categorized as

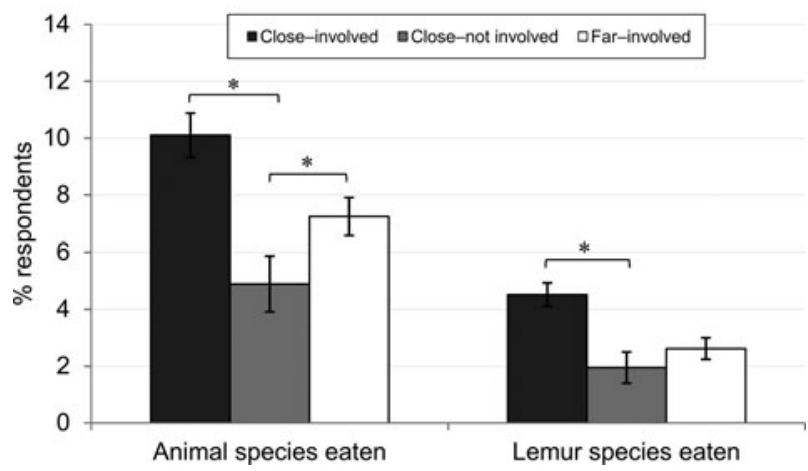

FIG. 5 Numbers (mean \pm SE) of animal and lemur species eaten by people in villages in the municipality of Iaboakoho, in south-east Madagascar (Fig. 1), categorized according to distance from the research station at Ampasy (Fig. 1) and continuous forest, and involvement in local forest management. The taboo species aye-aye Daubentonia madagascariensis and Madagascar red owl Tyto soumagnei are not included. ${ }^{\star} \mathrm{P}<0.05$.

close-involved $(\mathrm{P}<0.001)$ or far-involved $(\mathrm{P}=0.006)$. Also, people living in villages categorized as close-involved ate more species than those living in villages categorized as far-involved $(P=0.049)$. The number of lemur species that participants had eaten differed significantly between villages (distance-management effect: Wald $\chi^{2}=15.793, \mathrm{P}<0.001$ ). People living in villages categorized as close-involved declared they ate more lemur species than those living in villages categorized as close-not involved $(\mathrm{P}<0.001)$ or farinvolved $(\mathrm{P}=0.001)$.

The most widely consumed species in the area was the brown mesite Mesitornis unicolor, and the most commonly eaten lemur species was the collared brown lemur, followed by the southern bamboo lemur (Table 3). The aye-aye Daubentonia madagascariensis and Madagascar red owl Tyto soumagnei are taboo, although one person admitted to eating the latter. Most participants had eaten small Peters's sheath-tailed bats Paremballonura atrata and Anosy mouse lemurs Microcebus tanosi when young, or caught them for their children. Several participants sold ring-tailed mongoose Galidia elegans tails to Chinese people for traditional medicinal purposes.

\section{Snare and lemur counts}

The number of snares decreased significantly from 11 in 2012 (1.00 traps per $\mathrm{km}$ ) to four ( 0.36 traps per $\mathrm{km}$ ) in 2015 $(\mathrm{N}=11, Z=-2.121, \mathrm{P}=0.034)$, and further decreased significantly from 2015 to 2016 , when zero snares were found $(\mathrm{N}=11, Z=-2.000, \mathrm{P}=0.046)$.

The number of observations of cathemeral lemurs increased significantly between May-July 2015 and MayJuly $2016(\mathrm{~N}=27, Z=2.575, \mathrm{P}=0.010)$. During May-July 2015 we counted nine southern bamboo lemurs ( 0.33 
individuals per $\mathrm{km}$ and 0.07 groups per $\mathrm{km}$ ) and six collared brown lemurs ( 0.22 individuals per $\mathrm{km}$ and 0.04 groups per $\mathrm{km}$ ), and during May-July 2016 we counted 10 southern bamboo lemurs ( 0.37 individuals per $\mathrm{km}$ and 0.22 groups per $\mathrm{km}$ ) and 54 collared brown lemurs (2.00 individuals per $\mathrm{km}$ and 0.41 groups per $\mathrm{km}$ ).

\section{Discussion}

According to our findings the number of traps decreased after local management of the forest began, and decreased further after the installation of the research station. Furthermore, the encounter rate of cathemeral lemurs (the main targets for hunting) increased after the installation of the research station. Seventy-eight percent of participants declared they frequented the forest more often prior to local management commencing. These are indications that anthropogenic impacts on the area have been alleviated to some degree via forest management by Asity and KOMFITA. Impacts continued to decrease after the installation of the research station, mainly as a consequence of the increased involvement of villages categorized as close-involved.

\section{Impact of forest management}

The impact of local management is likely to be linked to the new job opportunities offered to local people and the actions to reduce impact on the forest. Approximately 20 people from villages categorized as far-involved were hired by Asity-KOMFITA to patrol the forest and reprimand those carrying out illegal activities. Other people, mainly from far-involved villages, were supported via training in sustainable agriculture. As part of the local management of the area a buffer zone was created in which local people are allowed to extract timber and firewood, and hunt exotic species (e.g. wild boar Sus scrofa; Razafitsalama \& Ravoahangy, 2010). The buffer zone includes small forest patches close to farinvolved villages. Conversely, the core zone, in which most of the Ampasy Valley is located, is patrolled regularly, and activities there are more strictly regulated. The effectiveness of this patrolling may be limited, however, as the agents do not have direct enforcement authority and they live in close proximity to the people they are meant to be reporting on (Reuter et al., 2017). Conflicting interests are thus likely to arise from this situation.

Some illegal activities, such as pirogue construction, appear to be still important in the area, as the municipality of Iaboakoho is the main pirogue supplier for Fort Dauphin (BirdLife International, 2011). Building a pirogue usually takes c. 1 month to complete, and pirogue builders often engage in other activities, such as opportunistic hunting (Gardner \& Davies, 2014). According to Asity reports, many pirogue builders have ceased this activity and are now employed within the community (Faniry Rakotoarimanana, pers. comm.). The dina (i.e. local law) includes fines (c. USD 3) for people caught building pirogues without permission, and to obtain this permission (only one pirogue is allowed per person) a tax must be paid to the local community (BirdLife International, 2011). However, pirogues can command prices of MGA 400,000-1,200,000 (USD 120360 ), which is well above the typical local monthly salary of c. MGA 150,000 (USD 45) (Faniry Rakotoarimanana, pers. comm.). One of the actions decided by the area local management committee is to destroy illegal pirogues found in the forest, which has effectively reduced pirogue production in recent years (Rakotoarimanana, 2016), although this previously created conflict between the NGO and local communities. The necessity to understand the needs of the community and mediate these with conservation goals is clear. It is crucial to consider the link between enforcement and incentives by implementing projects that could encourage individuals to engage less intensively in extractive activities, and ultimately modify these destructive behaviours (Reuter et al., 2017). Encouraging individuals to participate in alternative activities with similar profits, such as forest patrolling or sustainable agriculture, is an approach that needs to be strengthened, and is evident in the fact that most of the personnel hired at the research station were previously hunters and/or pirogue builders in the area.

Despite the use of indirect questioning techniques (Nuno \& St John, 2015), we realize that the results obtained via interviews could be biased, as participants may have been hesitant to declare their illegal activities (Knapp et al., 2010; Jenkins et al., 2011), especially if ongoing. In particular, inhabitants of villages categorized as close-not involved may have been more reluctant to admit to hunting and eating lemurs. They may also have been reluctant to declare that people from their villages or from neighbouring villages hunted at the same level as people living in close-involved and far-involved villages. From speaking informally with our collaborators it emerged that inhabitants of close-not involved villages have access to other areas of the forest far from the research station where opportunistic and snare hunting persists.

\section{Impact of researchers' presence}

The increase in encounter rates of cathemeral lemurs after the installation of the research station is probably not a result of factors such as patrolling and improved environmental conditions (e.g. habitat quality), as these factors remained stable between 2015 and 2016 (M. Campera, unpubl. data). Rather, it is likely that the presence of researchers favoured an increase in lemur encounter rates as a consequence of habituation of lemurs to human observers, and indirect deterrence of hunting. The main impact of researcher presence in 
TABLE 4 Details of local people employed by the research station at Ampasy (Fig. 1), with job, number of people employed, mean number of days worked per month, mean daily wage and mean monthly salary.

\begin{tabular}{lrrrr}
\hline Job & No. employed & $\begin{array}{c}\text { Mean no. of days } \\
\text { worked per month }\end{array}$ & $\begin{array}{l}\text { Mean daily wage } \\
\text { per person (MGA) }\end{array}$ & $\begin{array}{c}\text { Mean monthly salary } \\
\text { per person (MGA) }\end{array}$ \\
\hline Guide & $2-4^{\star}$ & 25 & 9,500 & 237,500 \\
Cook & 2 & 18 & 8,500 & 153,000 \\
Guardian & 2 & 18 & 8,000 & 144,000 \\
Porter & $8-20^{*}$ & 4 & 9,000 & 36,000 \\
Cleaner & 2 & 3 & 8,500 & 25,500 \\
Total & $16-30$ & $8.6-10$ & $8,800-8,900$ & $77,000-88,000$ \\
\hline
\end{tabular}

${ }^{*}$ Depending on the number of researchers at the research station (minimum: October-March; maximum: April-September)

TABLE 5 Estimated monthly consumption of products from the municipality of Iaboakoho by the personnel (researchers, volunteers and full-time employees) at the research station at Ampasy (Fig. 1).

\begin{tabular}{lc}
\hline Food type & Estimated monthly cost $(\mathrm{MGA})^{*}$ \\
\hline Meat & $80,000-110,000$ \\
Fish & $40,000-70,000$ \\
Rice \& manioc & $130,000-180,000$ \\
Vegetables \& legumes & $65,000-95,000$ \\
Other & $40,000-60,000$ \\
Total & $355,000-515,000$ \\
\hline
\end{tabular}

${ }^{*}$ Depending on the number of people at the research station (minimum: October-March; maximum: April-September)

terms of decreasing anthropogenic pressure is related to the creation of new job opportunities (Wrangham \& Ross, 2008; Schwitzer et al., 2014). Despite the limited number of fulltime employees (Table 4), the Ampasy research station employs several part-time workers from the local community. Employees were hired from various villages, with equal selection between sexes. Salaries are higher than the mean local salary, to favour positive community involvement, but not too high, to avoid social disequilibrium, as favouring individuals with high social standing and creating social disequilibrium has been indicated as a possible cause of failure of another forest management programme (Webber et al., 2007). Another important consequence of the research station was the contribution to the local economy through the purchase of food (Table 5). Thus, the food market for a fully operational research station near a small community such as Iaboakoho has the potential to generate new job opportunities and increase the income of local farmers. However, the management of the research station needs further improvement (e.g. constant and long-term presence of researchers) to increase the benefits across the local community.

\section{Implications and conclusion}

Longitudinal involvement by Asity-KOMFITA and the continuation of research projects in the area are pivotal in ensuring local sustainable development. Continuous monitoring is necessary to control the impact of anthropogenic activities over time and reliably estimate wildlife populations (Fedigan \& Jack, 2012; Nakamura, 2012). Promoting ecotourism may also increase community income and create alternative job opportunities for local people by conserving the forest (Schwitzer et al., 2014; but see Krüger, 2005 for the negative impacts of ecotourism on wildlife conservation). At present, however, promoting ecotourism in the Iaboakoho community is challenging because of the lack of a paved national road from Fort Dauphin (making an already remote site further inaccessible) and inadequate infrastructure. Besides the research station, additional development strategies are implemented by Asity-KOMFITA, such as sustainable farming, a tree nursery and reforestation, effective enforcement of the dina, and environmental education (Razafitsalama \& Ravoahangy, 2010; Rakotoarimanana, 2016; Balestri et al., 2017). All these activities have been shown to create long-term benefits for both local ecosystems and communities (Manjaribe et al., 2013). However, the effectiveness of these actions in the Tsitongambarika area and the timeline for their implementation remains to be seen.

In conclusion, it is evident that a combination of local management and related development strategies, such as the installation of a research station, can assist in significantly reducing forest exploitation by local communities. However, a prolonged effort to maintain conservation management is necessary to avoid failure of conservation programmes (Webber et al., 2007). Furthermore, illegal activities still persist in the area, especially in villages not involved in the local management. A full integration between community needs and conservation plans needs to be in place to maintain long-term benefits.

\section{Acknowledgements}

We thank the Department of Animal Biology (University of Antananarivo), Asity Madagascar-BirdLife International, QIT Madagascar Minerals, the Association of Managers of the Forests of Ambatoatsinana, the Community Forest Management of Iaboakoho, and the Ministère des Eaux et 
Forets for their collaboration and permission to work in Madagascar, and Faniry Rakotoarimanana, Nataud, Johny Rabenantoandro, Jean Baptiste Ramanamanjato, and our field assistants, translators and volunteers for their dedication and effort. We were supported by the Rufford Foundation (no. 16946-1), the Mohamed bin Zayed Species Conservation Fund (no. 142510128), Primate Conservation Inc. (no. 001185), the Conservation International Primate Action Fund (no. 1001423), and a Primate Society of Great Britain Conservation Grant (no. Feb_2014). We thank two anonymous reviewers for their helpful suggestions.

\section{Author contributions}

$\mathrm{MC}, \mathrm{MP}, \mathrm{FB}, \mathrm{MB}, \mathrm{VN}$ and GD conceived and designed the research. MC, MP, FB, MB and TME collected data. MC wrote the article, and MP, FB, MB, TME, VN and GD contributed revisions.

\section{References}

Allebone-Webb, S.M., Kümpel, N.F., Rist, J., Cowlishaw, G., Rowcliffe, J.M. \& Milner-Gulland, E.J. (2011) Use of market data to assess bushmeat hunting sustainability in Equatorial Guinea. Conservation Biology, 25, 597-606.

Balestri, M., Campera, M., Nekaris, K.A.I. \& Donati, G. (2017) Assessment of long-term retention of environmental education lessons given to teachers in rural areas of Madagascar. Applied Environmental Education \& Communication, http://dx.doi.org/10. 1080/1533015X.2017.1348275.

Barelli, C., Mundry, R., Araldi, A., Hodges, K., Rocchini, D. \& Rovero, F. (2015) Modeling primate abundance in complex landscapes: a case study from the Udzungwa Mountains of Tanzania. International Journal of Primatology, 36, 209-226.

Bezanson, M., Stowe, R. \& Watts, S.M. (2013) Reducing the ecological impact of field research. American Journal of Primatology, 75, 1-9.

Birdife International (2011) Tsitongambarika Forest, Madagascar. Biological and Socio-economic Surveys, with Conservation Recommendations. BirdLife International, Cambridge, UK.

Borgerson, C., McKean, M.A., Sutherland, M.R. \& Godfrey, L.R. (2016) Who hunts lemurs and why they hunt them. Biological Conservation, 197, 124-130.

Campbell, G., Kuehl, H., Diarrassouba, A., N'Goran, P.K. \& Boesch, C. (2011) Long-term research sites as refugia for threatened and over-harvested species. Biology Letters, 7, 723-726.

Donati, G., Campera, M., Balestri, M., Serra, V., Barresi, M., SCHwitzer, C. et al. (2016) Ecological and anthropogenic correlates of activity patterns in Eulemur. International Journal of Primatology, $37,29-46$.

Fedigan, L.M. \& JACK, K.M. (2012) Tracking Neotropical monkeys in Santa Rosa: lessons from a regenerating Costa Rican dry forest. In Long-Term Field Studies of Primates (eds P.M. Kappeler \& D.P. Watts), pp. 165-184. Springer-Verlag, Berlin, Germany.

Gardner, C.J. \& Davies, Z.G. (2014) Rural bushmeat consumption within multiple-use protected areas: qualitative evidence from southwest Madagascar. Human Ecology, 42, 21-34.
Golden, C.D. (2009) Bushmeat hunting and use in the Makira Forest north-eastern Madagascar: a conservation and livelihoods issue. Oryx, 43, 386-392.

Golden, C.D., Bonds, M.H., Brashares, J.S., Rasolofoniaina, B.J.R. \& Kremen, C. (2014) Economic valuation of subsistence harvest of wildlife in Madagascar. Conservation Biology, 28, 234-243.

Golden, C.D., Wrangham, R.W. \& Brashares, J.S. (2013) Assessing the accuracy of interviewed recall for rare, highly seasonal events: the case of wildlife consumption in Madagascar. Animal Conservation, 16, 597-603.

Henn, M., Weinstein, M. \& Foard, N. (2009) A Critical Introduction to Social Research. SAGE, Los Angeles, USA.

HiLl, C.M. (1997) Crop-raiding by wild vertebrates: the farmer's perspective in an agricultural community in western Uganda. International Journal of Pest Management, 43, 77-84.

Jenkins, R.K.B., Keane, A., Rakotoarivelo, A.R., RaKotomboavonjy, V., Randrianandrianina, F.H., Razafimanahaka, H.J. et al. (2011) Analysis of patterns of bushmeat consumption reveals extensive exploitation of protected species in eastern Madagascar. PLoS ONE, 6(12), e27570.

Knapp, E.J., Rentsch, D., Schmitt, J., Lewis, C. \& Polasky, S. (2010) A tale of three villages: choosing an effective method for assessing poaching levels in western Serengeti, Tanzania. Oryx, 44, 178-184.

KRUGER, O. (2005) The role of ecotourism in conservation: panacea or Pandora's box? Biodiversity and Conservation, 14, 579-600.

LitT LE, P.D. (1994) The link between local participation and improved conservation: a review of issues and experiences. In Natural Connections: Perspectives in Community-Based Conservation (eds D. Western, R.M. Wright \& S.C. Strum), pp. 347-372. Island Press, Washington, DC, USA.

Manjaribe, C., Frasier, C.L., Rakouth, B. \& Louis, Jr, E.E. (2013) Ecological restoration and reforestation of fragmented forests in Kianjavato, Madagascar. International Journal of Ecology, 2013, http://dx.doi.org/10.1155/2013/726275.

Marsh, C.W., Mohamed, M., Sinun, W. \& Sutton, S. (1999) The role of field centers in the conservation and management of tropical forests: a case study of the Danum Valley. In Environment and Conservation in Borneo (ed. P. Eaton), pp. 211-235. Borneo Research Council, Kota Kinabalu, Malaysia.

Melo, E.R.A., Gadelha, J.R., Da Silva, M.N.D., Da Silva Júnior, A.P. \& Pontes, A.R.M. (2015) Diversity, abundance and the impact of hunting on large mammals in two contrasting forest sites in northern Amazon. Wildlife Biology, 21, 234-245.

Myers, N., Mittermeier, R.A., Mittermeier, C.G., Da Fonseca, G.A.B. \& Kent, J. (2000) Biodiversity hotspots for conservation priorities. Nature, 403, 853-858.

Nakamura, M. (2012) Long-term field studies of chimpanzees at Mahale Mountains National Park, Tanzania. In Long-Term Field Studies of Primates (eds P.M. Kappeler \& D.P. Watts), pp. 339-356. Springer-Verlag, Berlin, Germany.

Newmark, W.D., Leonard, N.L., Sariko, H.I. \& Gamassa, D.M. (1993) Conservation attitudes of local people living adjacent to five protected areas in Tanzania. Biological Conservation, 63, 177-183.

N'Goran, P.K., Boesch, C., Mundry, R., N'Goran, E.K., Herbinger, I., Yapi, F.A. \& KÜHL, H.S. (2012) Hunting, law enforcement, and African primate conservation. Conservation Biology, 26, 565-571.

Nguyen, T., Eppley, T.M. \& Donati, G. (2013) Rapid assessment of lemur abundance in the lowland rainforest of Ampasy,

Tsitongambarika, south-east Madagascar. Lemur News, 17, 39-43. 
Nijman, V. (2005) Decline of the endemic Hose's langur Presbytis hosei in Kayan Mentarang National Park, East Borneo. Oryx, 39, 223-226.

Nijman, V. (2010) An overview of international wildlife trade from Southeast Asia. Biodiversity and Conservation, 19, 1101-1114.

Nuno, A. \& S T John, F.A.V. (2015) How to ask sensitive questions in conservation: a review of specialized questioning techniques. Biological Conservation, 189, 5-15.

Rakotoarimanana, F. (2016) Projet Offset Ampasy/Ivohibe (Bemangidy). Unpublished report. Asity Madagascar, Antananarivo, Madagascar.

RAo, M., ZAW, T., Htun, S. \& Myint, T. (2011) Hunting for a living: wildlife trade, rural livelihoods and declining wildlife in the Hkakaborazi National Park, North Myanmar. Environmental Management, 48, 158-167.

Razafimanahaka, J.H., Jenkins, R.K.B., Andriafidison, D., Randrianandrianina, F., Rakotomboavonjy, V., Keane, A. \& JONES, J.P.G. (2012) Novel approach for quantifying illegal bushmeat consumption reveals high consumption of protected species in Madagascar. Oryx, 46, 584-592.

Razafitsalama, L.J. \& Ravoahangy, A. (2010) Plan d'Aménagement et de Gestion de la Nouvelle Aire Protégée Tsitongambarika, Fort-Dauphin, Region Anosy. Unpublished report. Asity Madagascar, Antananarivo, Madagascar.

Reuter, K.E., Sewall, B.J. \& Di Minin, E. (2017) Drivers of present and lifetime natural resource use in a tropical biodiversity hotspot. Animal Conservation, http://dx.doi.org/10.1111/acv.12355.
Schwitzer, C., Mittermeier, R.A., Johnson, S.E., Donati, G., Irwin, M., PeAcock, H. et al. (2014) Averting lemur extinctions amid Madagascar's political crisis. Science, 343, 842-843.

Webber, A.D., Hill, C.M. \& Reynolds, V. (2007) Assessing the failure of a community-based human-wildlife conflict mitigation project in Budongo Forest Reserve, Uganda. Oryx, 41, 177-184.

Wrangham, R. \& Ross, E. (2008) Science and Conservation in African Forests: The Benefit of Long-Term Research. Cambridge University Press, Cambridge, UK.

Wright, P.C., Andriamihaja, B., King, S.J., Guerriero, J. \& Hubbard, J. (2014) Lemurs and tourism in Ranomafana National Park, Madagascar: economic boom and other consequences. In Primate Tourism: A Tool for Conservation? (eds A.E. Russon \& J. Wallis), pp. 123-146. Cambridge University Press, Cambridge, UK.

\section{Biographical sketches}

Marco Campera, Megan Phelps, Fiona Besnard and Michela BALESTRI study various aspects of lemur biology, including behavioural ecology and niche partitioning, commensalism with humans, and the role taboos and myths play in their conservation. Tімотну M. Eppley and Giuseppe Donati work on a wide range of nocturnal, cathemeral and diurnal lemur species, focusing on their behavioural ecology and working with Malagasy partners to improve their conservation status. VINCENT NIJM AN has a broad interest in primate conservation. 